\title{
Spatio-temporal analysis of host preferences and feeding patterns of malaria vectors in the sylvo-pastoral area of Senegal: impact of landscape classes
}

\author{
El Hadji Malick Ngom², Jacques-André Ndione ${ }^{3}$, Yamar Ba', Lassana Konaté2 ${ }^{1}$, Ousmane Faye ${ }^{2}$, Mawlouth Diallo \\ and Ibrahima Dia ${ }^{*}$
}

\begin{abstract}
Background: The study of vector feeding behaviour is an important step in the understanding of the epidemiology of vector borne diseases. The main objective of this work was to study the spatio-temporal host preferences and blood-feeding patterns of malaria vectors in a pastoral area of Senegal where cattle breeding is the main human activity.

Methods: Malaria vectors were collected indoors by pyrethrum spray catch in 16 villages belonging to 4 different landscape classes (wooded savanna, shrubby savanna, bare soils and steppe). Blood meals sources were determined using a direct enzyme-linked immunosorbent assay (ELISA).

Results: The blood meal origins of 1886 freshly fed An. gambiae s.l. were determined. Among these blood meals, most were taken on a single host: $40.1 \%$ on human and $37.1 \%$ on animal. The range in proportions of blood meals taken from human were $25-62.4 \%$ in wooded savanna villages, $23.5-61.9 \%$ in shrubby savanna villages, $31.3-70 \%$ in bare soils villages and $57.7-68.7$ in steppe villages. Blood meals taken from bovines were very heterogeneous with two clusters localized in the Northeast and Southwest axis of the study area that corresponds to the distribution of the main water ponds. Patent mixed blood meals taken from human and non-human were significantly higher than those taken from two animals, the highest proportions being observed in September (shrubby savanna, bare soils and steppe villages) or October (wooded savanna villages).

Conclusions: These observations suggest that in this pastoral area, differences in feeding patterns of malaria vectors are merely linked to the specific localization of villages and are not influenced by landscape class distribution. In addition, the temporal variations in the anthropophilic rates are influenced by the presence of standing water in the study area.
\end{abstract}

Keywords: An. gambiae s.l, Trophic preferences, Anthropophilic rates, Landscape classes, Blood meals, Pastoral area

\section{Background}

For many vector-borne diseases, the vector biting behaviour is an important factor in the epidemiology of the disease they transmit. Knowledge on the blood-feeding habits is important for implementation of effective vector control strategies [1]. In the case of malaria, the frequencies of Anopheles bites on humans affect the likelihood that a

\footnotetext{
*Correspondence: dia@pasteur.sn

'Unité d'Entomologie Médicale, Institut Pasteur de Dakar, 36 Avenue Pasteur, Dakar, BP 220, Sénégal

Full list of author information is available at the end of the article
}

mosquito in contact with a carrier of gametocytes becomes infected and able to transmit human Plasmodium. This probability is more important for vectors that exclusively bite only humans and reflects the degree of human-vector contact, which can be used in the implementation and evaluation of the impact of control measures [2].

Even though malaria is a non-transmissible pathogen between humans and animals, domestic animals can have a significant role in its epidemiology through the attraction or repulsion they may have on the vectors. Thus, in the prevention of transmission, domestic animals living in

\section{Biomed Central}

(c) 2013 Ngom et al.; licensee BioMed Central Ltd. This is an open access article distributed under the terms of the Creative Commons Attribution License (http://creativecommons.org/licenses/by/2.0), which permits unrestricted use, distribution, and reproduction in any medium, provided the original work is properly cited. 
close proximity to humans can attract anopheline vectors and thereby reduce the transmission of Plasmodium [3]. The interaction between humans and alternative hosts can be more pronounced in areas with a high concentration of livestock, particularly in pastoral areas. The presence of livestock in close proximity to human habitations may produce different trophic profiles including human or animal only or mixed blood meals from both [4]. This is the case in the main pastoral area of Senegal, where entomological studies showed heterogeneous trophic preferences of malaria vectors [5]. In this area livestock breeding is essentially traditional with a seasonal dynamic under the control of nomadic pastoralism largely linked to water and pasture availability. In fact, during the dry season, the lack of pasture and water lead to the concentration of cattle near the water boreholes and incite some herdsmen to leave the area. During the rainy season, they move back, thus increasing (in addition to the transhumant farmers from others regions of Senegal) substantially the population size of the livestock. This situation associated with the climatic conditions favourable for local vectors increase the risk of the emergence of vector-borne diseases such as Rift Valley and West Nile fevers that are endemic in this area [6], but might also affect malaria transmission.

The use of domestic animals living together with human populations to divert the blood-seeking vectors from human hosts has been suggested as an effective strategy for malaria control [7]. Studies conducted in Kenya have shown that the proportion of malaria vectors with human blood meals was significantly lower in areas with higher concentrations of domestic animals $[8,9]$ while Seyoum et al. [10] showed that the presence of cattle in homesteads tends to increase the man biting rates of malaria vectors. Therefore, the mosquitoes blood-feeding behaviour may be largely influenced by environmental factors in addition to their innate features [11]. Taking into account the spatial distribution of villages and hamlets as well as landscape classes, we analyzed the spatio-temporal host preferences and blood-feeding patterns of malaria vectors in the pastoral area of Ferlo, where cattle breeding is the main human activity.

\section{Methods}

\section{Presentation of the study area}

This study was conducted in 16 villages within the Sahelian region in the Sylvo-pastoral area of Senegal (Figure 1) from July to November 2009. The climate is typically Sahelian with a summer monsoon (the rainy season) that lasts from July to mid-October. Overall, the mean annual rainfall is mainly provided by squall lines, and ranges from $300 \mathrm{~mm}$ to $500 \mathrm{~mm}$. During the rainy season, a large quantity of small and temporary ponds is thus formed leading to an environment favouring mosquito breeding. These ponds are widely distributed, some isolated, and others organized in clusters of all sizes (Figure 1). The main known ponds are presented in Figure 1 (Niakha, Barkedji, Kangaledji and Beli Boda).

The population of this area is estimated at 14,200 inhabitants comprising of Fulani (85\%), Wolof (12\%), Moors and Serer (3\%). They grow mainly millet during the rainy season but cattle breeding is one of the main economic activities. Livestock including cattle, sheep, goats, poultry and equines (donkeys and horses) are the main domestic animals. Malaria transmission is seasonal in the study area and is transmitted predominantly by $A n$. arabiensis ([5,12], Dia et al., unpublished data).

During the dry season, farmers and their herds are concentrated near the water boreholes that remain the only available water points during that period whereas during the rainy season, the tranhumance from all breeding regions of Senegal bring a large number of farmers and their cattle into this region in search of pasture and water surfaces for livestock needs.

Within the study area, four different landscape classes were defined using remote sensing and geospatial analyses from a SPOT 5 satellite image based on the description of the vegetation classes according to the combination of the FAO [13] and CSA [14] systems. All 16 sampling sites were geo-referenced with a hand-held GPS receiver and each of them was classified to the corresponding landscape class (Figure 1, Table 1).

\section{Mosquito sampling and processing}

Adults resting mosquitoes were collected using the Pyrethrum Spray Catch method in selected bedrooms from July to November 2009. Upon collection, anopheline vectors were sorted, counted and morphologically identified following the key of Gillies \& de Meillon [15]. Blood meals from blood-fed mosquitoes were collected onto filter paper for subsequent determination of the host source. The origin of blood meals was identified using an enzyme-linked immunosorbent assay (ELISA) according to Beier et al. [16] using peroxidase-conjugated antibodies (Kirkegaard and Perry, Gaithersburg, MD). The choice of antibodies was made by taking into account the prevalent domestic animals present in the study villages. Thus, five different antibodies were used: anti-human, anti-bovine, anti-ovine, anti-chicken and anti-equine. All blood meals sources were determined simultaneously using the five antibodies.

\section{Data analysis}

Data were entered into Microsoft Excel and analysed using the R Gui software (v.3.0.2). The proportions of blood meals taken on each of the five vertebrate hosts tested were estimated by the percentage of the number of blood meals taken on each host over the total number of blood meals identified. 


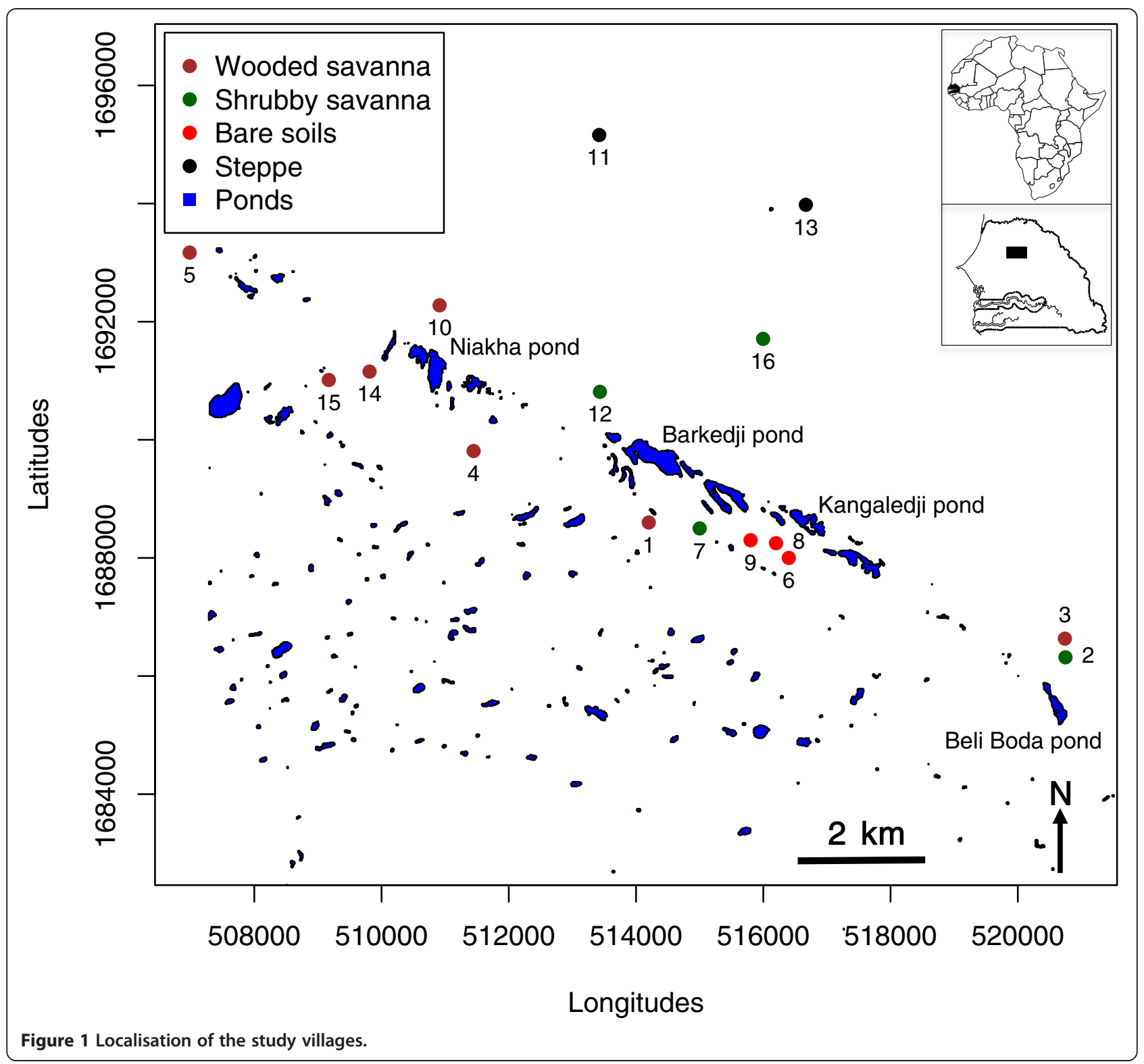

The anthropophilic rates were calculated as the proportion of the mosquitoes that fed on humans out of the total blood meals determined. For each study site, the proportions of patent mixed blood meals were calculated as the proportion of mosquitoes fed at least on two different vertebrate hosts over the total blood meals identified. The chi-squared test was used to compare the proportions of blood meals whereas analysis of variance (ANOVA) was used to compare the mean proportions of blood meals between landscape classes.

To study the influence of landscape classes on trophic preferences, the proportions of blood meals between sites belonging to the same landcape class were compared and pooled to assess their association with the trophic profile of the vectors.

\section{Results}

A total of 1886 blood meals from An. gambiae s.l. resting females were tested by ELISA (Table 2). Most of these blood meals were taken on a single host (human or animal). The percentage of non-reacting blood meals was estimated to be $8.4 \%$ whereas $14.4 \%$ of blood meals were taken on two different vertebrate hosts. All the blood meals sampled from the bare soil landscape were identified. The proportions of non-identified blood meals were statistically comparable between the three other landscape classes $\left(\chi^{2}=4.8, \mathrm{df}=2, \mathrm{p}=0.09\right)$.

\section{Trophic preferences}

Within the study area, the majority of blood meals were of human (40.1\%) origin followed by bovine (16.1\%). The 
Table 1 Main characteristics of the study sites

\begin{tabular}{|c|c|c|c|c|}
\hline $\mathbf{N}^{\circ}$ sites & Villages & Latitude $\mathrm{N}$ & Longitude W & Land cover type \\
\hline 1 & Barkedji & $15^{\circ} 17^{\prime}$ & $14^{\circ} 53^{\prime}$ & Wooded savanna \\
\hline 2 & Keur Alpha Goudal & $15^{\circ} 14^{\prime}$ & $14^{\circ} 47^{\prime}$ & Shrubby savanna \\
\hline 3 & Keur Racine Sow & $15^{\circ} 15^{\prime}$ & $14^{\circ} 47^{\prime}$ & Wooded savanna \\
\hline 4 & Dague Nabe & $15^{\circ} 17^{\prime}$ & $14^{\circ} 52^{\prime}$ & Wooded savanna \\
\hline 5 & Diabal & $15^{\circ} 18^{\prime}$ & $14^{\circ} 56^{\prime}$ & Wooded savanna \\
\hline 6 & Keur Dadal Sow & $15^{\circ} 16^{\prime}$ & $14^{\circ} 51^{\prime}$ & Bare soil \\
\hline 7 & Keur Adama Sow & $15^{\circ} 16^{\prime}$ & $14^{\circ} 51^{\prime}$ & Shrubby savanna \\
\hline 8 & Keur Aliou Diallo & $15^{\circ} 15^{\prime}$ & $14^{\circ} 50^{\prime}$ & Bare soil \\
\hline 9 & Keur Gallo Sow & $15^{\circ} 16^{\prime}$ & $14^{\circ} 51^{\prime}$ & Bare soil \\
\hline 10 & Keur Adama & $15^{\circ} 17^{\prime}$ & $14^{\circ} 53^{\prime}$ & Wooded savanna \\
\hline 11 & Keur Bandji & $15^{\circ} 19^{\prime}$ & $14^{\circ} 52^{\prime}$ & Steppe \\
\hline 12 & Keur Demba & $15^{\circ} 17^{\prime}$ & $14^{\circ} 52^{\prime}$ & Shrubby savanna \\
\hline 13 & Keur Diallo & $15^{\circ} 19^{\prime}$ & $14^{\circ} 50^{\prime}$ & Steppe \\
\hline 14 & Niakha & $15^{\circ} 17^{\prime}$ & $15^{\circ} 54^{\prime}$ & Wooded savanna \\
\hline 15 & Niakha Ndiaybe & $15^{\circ} 15^{\prime}$ & $14^{\circ} 50^{\prime}$ & Wooded savanna \\
\hline 16 & Wouro Samba Kibel & $15^{\circ} 17^{\prime}$ & $14^{\circ} 51^{\prime}$ & Shrubby savanna \\
\hline
\end{tabular}

Table 2 Number and percentage of An. gambiae resting females fed on each of the 5 vertebrate hosts tested in the study villages

\begin{tabular}{|c|c|c|c|c|c|c|c|c|c|}
\hline \multirow{2}{*}{$\begin{array}{l}\text { Landscape } \\
\text { classes/villages }\end{array}$} & \multirow[b]{2}{*}{ Number tested } & \multicolumn{5}{|c|}{ Single blood meals } & \multicolumn{2}{|c|}{ Mixed blood meals } & \multirow[b]{2}{*}{ Undeterminec } \\
\hline & & Human & Bovine & Ovine & Chicken & Equine & Animal/Animal & Human/Animal & \\
\hline \multicolumn{10}{|l|}{ Wooded savanna } \\
\hline Barkedji & 675 & $237(35.1)$ & $90(13.3)$ & $57(8.4)$ & $6(0.9)$ & $139(20.6)$ & $0(0)$ & 77 (11.4) & $69(10.2)$ \\
\hline Keur Racine Sow & 80 & $28(35)$ & $7(8.8)$ & $9(11.3)$ & $0(0)$ & $11(13.8)$ & $0(0)$ & $3(3.8)$ & $22(27.5)$ \\
\hline Dague Nabe & 134 & $79(59)$ & $4(3)$ & $9(6.7)$ & $0(0)$ & $10(7.5)$ & $0(0)$ & $20(14.9)$ & $12(9.0)$ \\
\hline Diabal & 141 & $88(62.4)$ & $3(2.1)$ & $6(4.3)$ & $0(0)$ & $24(17)$ & $0(0)$ & $13(9.2)$ & $7(5.0)$ \\
\hline Keur Adama & 26 & $8(30.8)$ & $2(7.7)$ & $8(30.8)$ & $0(0)$ & $3(11.5)$ & $0(0)$ & $3(11.5)$ & $2(7.7)$ \\
\hline Niakha & 120 & $43(35.8)$ & $33(27.5)$ & $8(6.7)$ & $8(6.7)$ & $0(0)$ & $0(0)$ & $7(5.8)$ & $21(17.5)$ \\
\hline Niakha Ndiaybe & 308 & $77(25)$ & $104(33.8)$ & $9(2.9)$ & $5(1.6)$ & $29(9.4)$ & $1(0.3)$ & $78(25.3)$ & $5(1.6)$ \\
\hline \multicolumn{10}{|l|}{ Shrubby savanna } \\
\hline Keur Alpha Goudal & 136 & $32(23.5)$ & $44(32.4)$ & $9(6.6)$ & $0(0)$ & $8(5.9)$ & $0(0)$ & $30(22.1)$ & $13(9.6)$ \\
\hline Keur Adama Sow & 21 & $13(61.9)$ & $3(14.3)$ & $0(0)$ & $0(0)$ & $4(19)$ & $0(0)$ & $1(4.8)$ & $0(0)$ \\
\hline Keur Demba & 25 & $12(48)$ & $0(0)$ & $2(8)$ & $1(4)$ & $0(0)$ & $0(0)$ & $9(36)$ & $1(4)$ \\
\hline Wouro Samba Kibel & 42 & $26(61.9)$ & $0(0)$ & $5(11.9)$ & $0(0)$ & $4(9.5)$ & $0(0)$ & $7(16.7)$ & $0(0)$ \\
\hline \multicolumn{10}{|l|}{ Bare soil } \\
\hline Keur Dadal Sow & 17 & $11(64.7)$ & $2(11.8)$ & $1(5.9)$ & $0(0)$ & $1(5.9)$ & $0(0)$ & $2(11.8)$ & $0(0)$ \\
\hline Keur Aliou Diallo & 16 & $5(31.3)$ & $5(31.3)$ & $0(0)$ & $0(0)$ & $3(18.8)$ & $0(0)$ & $3(18.8)$ & $0(0)$ \\
\hline Keur Gallo Sow & 20 & $14(70)$ & $3(15)$ & $0(0)$ & $0(0)$ & $1(5)$ & $0(0)$ & $2(10)$ & $0(0)$ \\
\hline \multicolumn{10}{|l|}{ Steppe } \\
\hline Keur Bandji & 26 & $15(57.7)$ & $0(0)$ & $0(0)$ & $0(0)$ & $6(23.1)$ & $0(0)$ & $3(11.5)$ & $2(7.7)$ \\
\hline Keur Diallo & 99 & $68(68.7)$ & $4(4)$ & $1(1)$ & $0(0)$ & $8(8.1)$ & $0(0)$ & $14(14.1)$ & $4(4)$ \\
\hline Total & 1886 & $756(40.1)$ & $304(16.1)$ & $124(6.6)$ & $20(1.1)$ & $251(13.3)$ & $1(0.1)$ & $272(14.4)$ & $158(8.4)$ \\
\hline
\end{tabular}

(): Percentage (\%). 
remaining blood meals were from equines (13.3\%), ovine (6.6\%) and chicken (1.1\%).

Only one patent mixed blood meal was taken on two different non-human hosts in a village of wooded savanna (Niakha), while mixed blood meals taken from human and non-human host were more frequent and were observed in all villages (Table 2). The highest proportions of these mixed blood meals were observed in September (shrubby savanna, bare soil and steppe villages) or October in wooded savanna villages (Figure 2). No significant difference was observed between the number of patent mixed blood meals between the four landscape classes for each month $\left(\mathrm{F}_{3,12}=0.71, \mathrm{p}=0.6\right.$ for July, $\mathrm{F}_{3,12}=2.2, \mathrm{p}=0.1$ for August, $F_{3,12}=3.4, p=0.8$ for September, $F_{3,12}=0.9$, $\mathrm{p}=0.5$ for October, $\mathrm{F}_{3,12}=0.7, \mathrm{p}=0.6$ for November).

Spatially, in almost all villages, blood meals taken from humans were predominantly observed. Blood meals taken from bovine were very heterogeneous and seem to constitute two clusters localized respectively around Kangaledji and Niakha ponds (Figure 3). The proportions of blood meals taken from ovine were relatively low (between 1 and $31 \%$ ) and were observed in 12 out of the 16 villages (Figure 3). Blood meals from chicken were observed only in two wooded savanna villages (Barkedji and Niakha) whereas blood meals from equines were observed in all villages (except in two villages from wooded savanna and 1 village from shrubby savanna).

\section{Anthropophilic rates}

The range of the proportions of blood meals taken from humans were $25-62.4 \%, 23.5-61.9 \%, 31.3-70 \%$ and $57.7-68.7 \%$ respectively in wooded savanna, shrubby savanna, bare soils and steppe villages. These variations were statistically different between wooded savanna villages $\left(\chi^{2}=86.4, \mathrm{df}=6, \mathrm{p}<0.0001\right)$ and shrubby savanna villages $\left(\chi^{2}=28.6, \mathrm{df}=3, \mathrm{p}<0.0001\right)$ but neither between bare soils villages $\left(\chi^{2}=6.1, \mathrm{df}=3, \mathrm{p}=0.11\right)$ nor between steppe villages $\left(\chi^{2}=0.7, \mathrm{df}=1, \mathrm{p}=0.41\right)$.

The anthropophilic rates were heterogeneous in July at the beginning of the rainy season (Figure 4). The highest proportions (range 90-100\%) were observed only in 7 villages ( 4 in wooded savanna, 2 in shrubby savanna, 1 both in steppe and bare soils). It was mainly during the rainy season (August and September) that the blood meals taken from human were widespread and homogenously distributed in the study area. The anthropophilic rates were higher in September than in August (range 33.3-83.3; 34.1-97.8\% respectively in August and September in wooded savanna villages, 20-66.7\% in August and 37.3$100 \%$ in September in Shrubby savanna villages). For villages from bare soil and steppe, the differences were less marked but the blood meals taken from humans were more uniformly distributed in September (Figure 4).

At the end of the rainy season, the anthropophilic rates were low in shrubby savanna villages and bare soil whereas

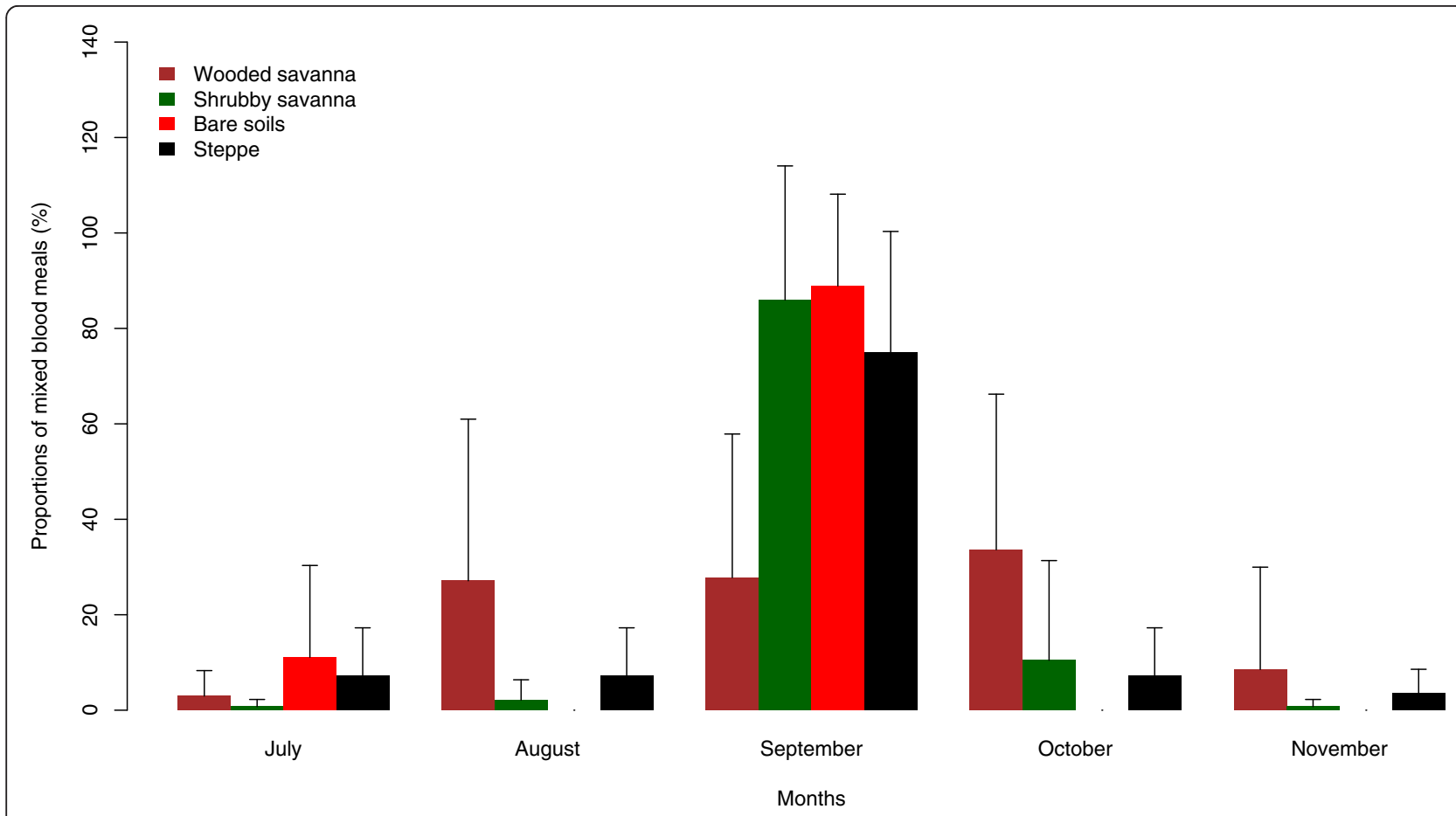

Figure 2 Temporal variations of mixed blood meals (Human/Animal) type within each of the four landscape classes identified in the study area. 

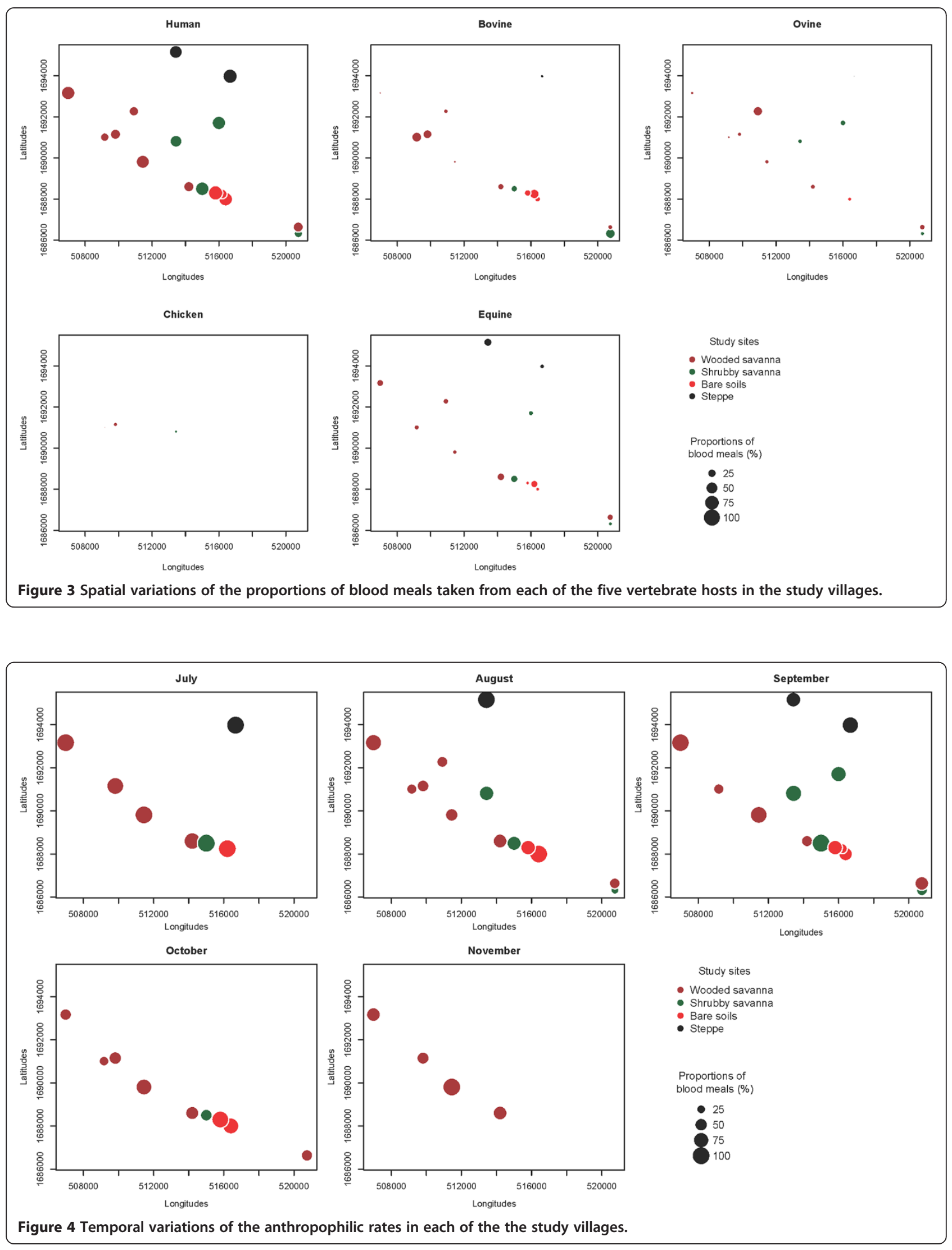
no blood meal from humans was observed in steppe villages in November. In wooded savanna villages, the anthropophilic rates increased in October (between 30 and 79.3\%) and November (between 46.6 and 100\%).

\section{Discussion}

The evaluation of mosquito vectors host preferences is difficult under natural conditions and depends on the sampling techniques used [17]. Besides mosquito species with a highly specific feeding behaviour, there are other vectors whose feeding habits depend largely on the presence and accessibility of alternative hosts [18]. Thus, to avoid and minimize the potential bias due to the sampling method used, and to be able to compare the feeding habits of mosquitoes between villages and landscape classes, blood fed females were collected in human houses and far away from storehouses, pens and other livestock shelters.

Our results showed that single blood meals on human or animal were predominantly observed in comparison to patent mixed blood meals. In each of the four landscape classes, blood meals taken from humans were more frequently observed. The proportions of these blood meals could be underestimated as the ELISA method used is unable to detect multiple cryptic blood meals on humans whereas the inclusion of the frequencies of these blood meals may contribute to a better estimation of the entomological inoculation rate $[19,20]$. Inversely, the existence of single blood meals on animals could be a barrier to malaria transmission [21]. For this reason many human communities have intentionally used cattle near or inside human habitations in order to divert mosquitoes from humans to cattle [22].

On the other hand, almost all patent mixed blood meals were taken from humans and animals with observed proportions up to $36 \%$ in a shrubby savanna village. This may contribute to a reduction in transmission through a loss of Plasmodium. Indeed, Muriu et al. [3] suggested that during mixed feeding in non-human hosts, a loss of certain number of sporozoites is expected and could be of importance in malaria control. Such phenomenon would be more marked in wooded savanna villages and to a lesser extent in shrubby savanna villages where the highest proportions of mixed blood meals were observed. This situation may indicate that mixed herds are rare in the study area and/or human populations live in close proximity with livestock. Overall, the highest proportions of these mixed blood meals were observed in September in shrubby savanna, bare soil and steppe villages or in October in wooded savanna villages. This period corresponds to the period of highest mosquitoes densities in the area ([5,23], Dia et al. Unpublished data). This observation could be the result of hosts defence reactions against high vector abundance as suggested by Boreham \&
Garrett-Jones [24]. Therefore, several feedings are necessary in the same gonotrophic cycle to achieve complete repletion.

Depending on the villages, most of the single blood meals were taken from humans, equines and to a lesser extent from ovines. Previous studies on trophic preferences in the Barkedji village have shown the predominance of human and bovine blood meals [5]. Although less widely distributed, the proportions of blood meals from bovine were relatively important and associated with bare soil villages (south-western part of the study area) and two wooded savanna villages (Niakha and Niakha Ndiaybe situated in the north-western part of the study area). Indeed, the bare soil landscape in this zone, is where the livestock is preferentially parked including big ruminants (around Kangaledji pond). The two villages from wooded savanna (Niakha and Niakha Ndiaybe) are settled near one of the biggest water ponds in this area (Niakha pond), that constitutes the main source of water for humans as well as livestock. Therefore it is expected that mosquitoes that took their blood meals from these animals, rest inside human houses in these two villages.

The more widely distributed blood meals from humans and ovines can be explained by the availability of these hosts whatever the village or landscape classes considered. In fact, in the majority of houses in wooded savanna villages, small ruminants including sheep and goats are kept inside human habitations. The low proportions of blood meals taken from chicken are the result of a rarity of this host and/or a reduced attraction of the vectors as already shown in the area [5] or elsewhere in Senegal [25].

Our data exhibit widely dispersed blood meals taken from humans during August and September in the study area. During this period water and pasture are available for livestock. Thus, most of the cattle herds are left far away from human habitations, reducing thereby the contacts with human hosts and the possibility of blood meals on livestock. In October and November, the distribution of human blood meals is restricted to the villages situated along the north-western and south-eastern axis that correspond to the distribution chain of the main residual water ponds in the area in this period. Our observations suggest, therefore, that the observed differences are merely due to the specific localization of villages and are not influenced by the types of landscape classes. In addition, the presence of wide grazing surfaces around villages of steppe, bare soil and shrubby savanna keep animals distant to the human environment, while in wooded savanna villages, livestock usually live in close proximity with humans in the domestic and peridomestic environment.

\section{Conclusions}

This study has demonstrated that in this pastoral area, malaria vectors show heterogeneous trophic preferences 
linked to the specific localization and seem not to be influenced by the distribution of landcape classes. It has further revealed that the temporal variations of malaria vector anthropophilic rates are influenced by the presence of standing water in the study area. Hence, any strategy for controlling malaria vectors in this area should take into account this heterogeneity for better control measure choices and implementation.

\section{Competing interests}

The authors declare that they have no competing interests.

\section{Authors' contributions}

ID, LK, OF and MD designed and supervised the study. ID, EMN, JAN and YB performed field and laboratory activities. ID, EMN, MD analyzed the data, drafted and revised the manuscript. All authors revised and approved the final version of the manuscript.

\section{Acknowledgments}

We are grateful to Sadio Sow for his technical assistance and help during field investigations and the villagers for their cooperation and their active participation in this study. This study was funded by the EU project QWeCl (Quantifying Weather and Climate Impacts on health in developing countries; funded by the European Commission's Seventh Framework Research Programme under the grant agreement 243964) and the Fonds d'Impulsion de la Recherche Scientifique et Technologique (Ministère de la Recherche du Sénégal).

\section{Author details}

'Unité d'Entomologie Médicale, Institut Pasteur de Dakar, 36 Avenue Pasteur, Dakar, BP 220, Sénégal. 'Laboratoire d'Ecologie Vectorielle et Parasitaire, Université Cheikh Anta Diop de Dakar, Dakar, Senegal. ${ }^{3}$ Centre de Suivi Ecologique, Dakar, Senegal.

Received: 29 July 2013 Accepted: 14 November 2013 Published: 19 November 2013

\section{References}

1. Tirados I, Costantini C, Gibson G, Torr SJ: Blood-feeding behaviour of the malarial mosquito Anopheles arabiensis: implications for vector control. Med Vet Entomol 2006, 20:425-437.

2. Garrett-Jones C, Boreham PFL, Pant CP: Feeding habits of anophelines (Diptera: Culicidae) in 1971-1978, with reference to the human blood index: a review. Bull Entomol Res 1980, 70:165-185.

3. Muriu SM, Muturi EJ, Shililu JI, Mbogo CM, Mwangangi JM, Jacob BG, Irungu LW, Mukabana RW, Githure JI, Novak RJ: Host choice and multiple blood feeding behaviour of malaria vectors and other anophelines in Mwea rice scheme, Kenya. Malar J 2008, 7:43

4. Massebo F, Balkew M, Gebre-Michael T, Lindtjørn B: Blood meal origins and insecticide susceptibility of Anopheles arabiensis from Chano in South-West Ethiopia. Parasit Vectors 2013, 6:44.

5. Lemasson JJ, Fontenille D, Lochouarn L, Dia I, Simard F, Ba K, Diop A, Diatta M, Molez JF: Comparison of behavior and vector effciency of Anopheles gambiae and An. arabiensis (Diptera: Culicidae) in Barkedji, a sahelian area of Senegal. J Med Entomol 1997, 34:396-403.

6. Traoré-Lamizana M, Fontenille D, Diallo M, Ba Y, Zeller HG, Mondo M, Adam F, Thonon J, Maiga A: Arbovirus surveillance from 1990 to 1995 in the Barkedji area (Ferlo) of Senegal, a possible natural focus of Rift Valley Fever virus. J Med Entomol 2001, 38(4):480-492.

7. Mahande A, Mosha F, Mahande J, Kweka E: Feeding and resting behaviour of malaria vector, Anopheles arabiensis with reference to zooprophylaxis. Malar J 2007, 6:100.

8. Githeko AK, Service MW, Mbogo CM, Atieli FK, Juma FO: Origin of blood meals in indoor and outdoor resting malaria vectors in western Kenya. Acta Trop 1994, 58(3-4):307-316.

9. ljumba JN, Mwangi RW, Beier JC: Malaria transmission potential of Anopheles mosquitoes in the Mwea-Tebere irrigation scheme, Kenya. Med Vet Entomol 1990, 4(4):425-432
10. Seyoum A, Balcha F, Balkew M, Ali A, Gebre-Michael T: Impact of cattle keeping on human biting rate of anopheline mosquitoes and malaria transmission around Ziway, Ethiopia. East Afr Med J 2002, 79(9):485-490.

11. Tuno N, Kjaeransen J, Badu K, Kruppa T: Blood-feeding behaviour of Anopheles gambiae and Anopheles melas in Ghana, West Africa. J Med Entomol 2010, 47(1):28-31.

12. Dia I, Diallo D, Duchemin JB, Ba Y, Konate L, Costantini C, Diallo M: Comparisons of human-landing catches and odor-baited entry traps for sampling malaria vectors in Senegal. J Med Entomol 2005, 42(2):104-109.

13. FAO: Africover, classification de l'occupation du sol. RSC Series; 1997. 70, 80pp.

14. Conseil Scientifique pour l'Afrique (CSA): Phytogéographie (Yangambi). Londres: CCTA; 1956:35.

15. Gillies MT, De Meillon B: The Anophelinae of Africa South of the Sahara, 2nd edition. Publ South Afr Ins Med Res 1968, 54:12-36.

16. Beier JC, Perkins PV, Wirtz RA, Koros J, Diggs D, Gargan TP II, Koech DK: Blood meal identification by direct Enzyme-linked immunosorbent assay (ELISA), tested on Anopheles (Diptera: Culicidae) in Kenya. J Med Entomol 1988, 25:9-16.

17. Garrett-Jones C: The human blood index of malaria vectors in relation to epidemiological assessment. Bull World Health Organ 1964, 30:241-261.

18. Lyimo IN, Ferguson HM: Ecological and evolutionary determinants of host species choice in mosquito vectors. Trends Parasitol 2009, 25(4):189-196.

19. Norris LC, Fornadel CM, Hung WC, Pineda FJ, Norris DE: Frequency of multiple blood meals taken in a single gonotrophic cycle by Anopheles arabiensis mosquitoes in Macha, Zambia. Am J Trop Med Hyg 2010, 83(1):33-37.

20. Scott TW, Takken W: Feeding strategies of anthropophilic mosquitoes result in increased risk of pathogen transmission. Trends Parasitol 2012, 28(3):114-121

21. Bruce-Chwatt LJ, Garrett-Jones C, Weitz B: Ten year study (1955-1964) of host selection by anopheline mosquitoes. Bull World Health Organ 1966, 35:405-439.

22. Burkot TR, Graves PM, Paru R, Lagog M: Mixed blood feeding by the malaria vectors in the Anopheles punctulatus complex (Diptera: Culicidae). J Med Entomol 1988, 25:205-213.

23. Ba Y, Diallo D, Dia I, Diallo M: Comportement trophique des vecteurs du virus de la fièvre de la vallée du Rift: implications dans l'épidémiologie de la maladie. Bull Soc Path Ex 2006, 99(4):283-289.

24. Boreham PFL, Garrett-Jones C: Prevalence of mixed blood meals and double feeding in a malaria vector (Anopheles sacharovi Favre) Bull World Health Organ 1973, 48:605-614.

25. Konaté L, Faye O, Gaye O, Sy N, Diop A, Diouf M, Trape JF, Molez JF: Zoophagie et hôtes alternatifs des vecteurs du paludisme au Sénégal. Parasite 1999, 6(3):259-267.

doi:10.1186/1756-3305-6-332

Cite this article as: Ngom et al: Spatio-temporal analysis of host preferences and feeding patterns of malaria vectors in the sylvo-pastoral area of Senegal: impact of landscape classes. Parasites \& Vectors 2013 6:332

\section{Submit your next manuscript to BioMed Central and take full advantage of:}

- Convenient online submission

- Thorough peer review

- No space constraints or color figure charges

- Immediate publication on acceptance

- Inclusion in PubMed, CAS, Scopus and Google Scholar

- Research which is freely available for redistribution 